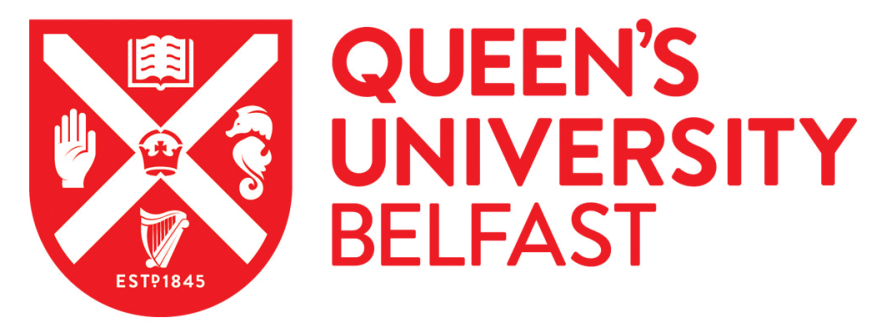

\title{
The extent and impact of musculoskeletal dysfunction on women following breast reconstruction using the Latissimus Dorsi muscle. A questionnaire survey
}

Blackburn, N. E., McVeigh, J. G., Wilson, I., \& McCaughan, E. (2016). The extent and impact of musculoskeletal dysfunction on women following breast reconstruction using the Latissimus Dorsi muscle. A questionnaire survey. Poster session presented at National Cancer Research Institute, Liverpool, United Kingdom.

Document Version:

Other version

Queen's University Belfast - Research Portal:

Link to publication record in Queen's University Belfast Research Portal

Publisher rights

Copyright 2016 The Authors.

\section{General rights}

Copyright for the publications made accessible via the Queen's University Belfast Research Portal is retained by the author(s) and / or other copyright owners and it is a condition of accessing these publications that users recognise and abide by the legal requirements associated with these rights.

Take down policy

The Research Portal is Queen's institutional repository that provides access to Queen's research output. Every effort has been made to ensure that content in the Research Portal does not infringe any person's rights, or applicable UK laws. If you discover content in the Research Portal that you believe breaches copyright or violates any law, please contact openaccess@qub.ac.uk. 


\title{
The Musculoskeletal Consequences of Breast Reconstruction using the Latissimus Dorsi Muscle: A Focus Group Study
}

\author{
Ms Nicole Blackburn', Dr Joseph G McVeigh², Professor Eilis McCaughan ${ }^{3}$ \& Dr Iseult M Wilson ${ }^{2}$
}

\section{Background}

A breast cancer diagnosis and consequent treatments, which often include mastectomy, can be extremely distressing for women. Breast reconstruction following mastectomy is considered an important management option for women to consider [1]. The latissimus dorsi (LD) flap is one of the most widely used surgical procedures for

women with breast cancer undergoing reconstructive surgery [2,3]. However, one common, but often ignored, complication following LD flap reconstruction is shoulder dysfunction [4,5]. Previous literature surrounding the impact of LD breast reconstruction has mainly focused on body image, aesthetic results and wound healing [6] with little in-depth investigation of the impact of this surgery on shoulder function [7]. The aim of this study, therefore, was to determine the musculoskeletal consequences of breast reconstruction using LD, and their impact on function and quality of life, as perceived by patients.

\section{Methodology}

Three focus groups were conducted with women who had undergone reconstructive surgery $(n=15)$

Women also completed a profile form which collected demographical information including; age, diagnosis, staging of breast cancer, cancer treatments and timelines

Shoulder movement was also assessed at the time of the focus groups

All focus groups were audio and video recorded, inductive content analysis was used to analyse transcripts and to develop core themes and sub-themes. A second level of analysis was also conducted whereby information from the participant profiles and the shoulder movement analysis were mapped to the participant's individual statements.

\section{Results}

Common Functional Difficulties Reported ( $\geq 1$ year post-op)

Tightness in the shoulder and back Pain and discomfort in the donor site Weakness in grip Inability to carry heavy weights Numbness Reduced power Cramping Fatigue

Despite all women encountering various challenges and facing ongoing problems throughout their journey, the women remained positive and reflected on their experience in an optimistic light.
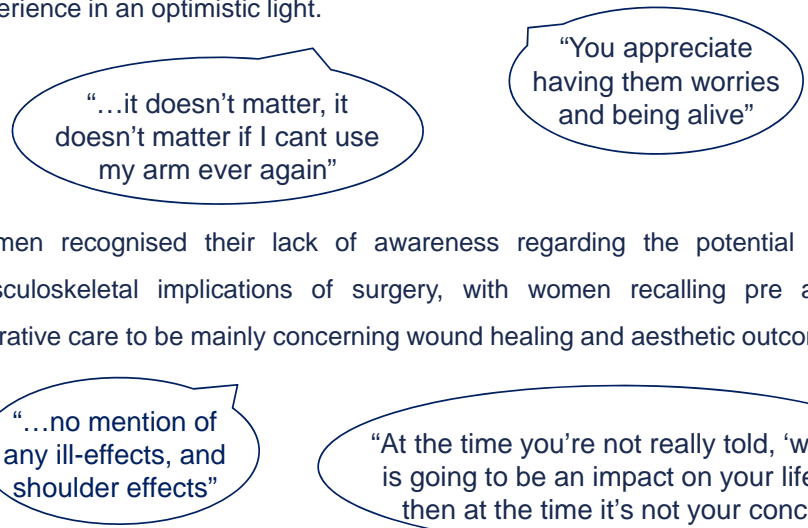

\section{atter, it}

use
doesn't matter if I cant us my arm ever again"

"

Women recognised their lack of awareness regarding the potential long-term musculoskeletal implications of surgery, with women recalling pre and postoperative care to be mainly concerning wound healing and aesthetic outcome.

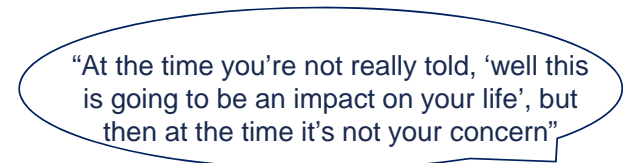

However, it was apparent that the relative importance of overcoming the cancer and recovering from the adjuvant treatments was of higher priority than the potential of reduced function of the shoulder, following surgery.
It was evident from the data that few, if any of the women recovered to their presurgery state of shoulder function or strength. Nonetheless, the women accepted this as a consequence of surgery and as a result, accommodated a 'new normal'.

Consequently, 'Resilience' emerged as the overarching theme from the data. Furthermore, three sub-themes emerged including; preparation and awareness, coping and self-management.

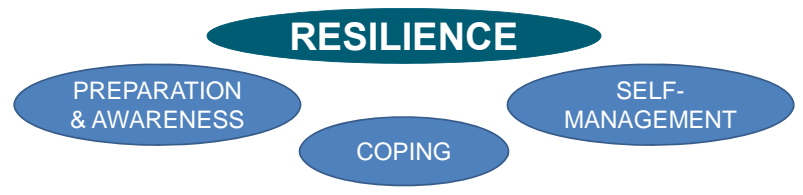

Further analysis revealed that based on participant characteristics there were no major influencing factors on the perceived impact of LD breast reconstruction.

$\begin{array}{lcc}\text { Participant Characteristics } & \text { Number } & \% \\ \text { Age (years) } & & \\ \text { Mean (SD) } & 56(7.5) & \\ \text { Range } & 45-71 & \\ \text { Operated Side } & 6 & 40 \\ \text { Dominant } & 9 & 60 \\ \text { Non-dominant } & & \\ \text { Time since Reconstruction (months) } & 62(28.9) & \\ \text { Mean (SD) } & 12-112 & \\ \text { Range } & & \end{array}$

\section{Conclusions}

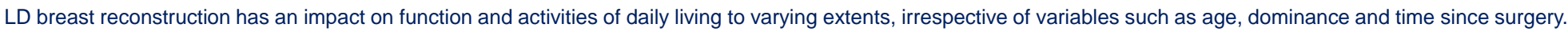

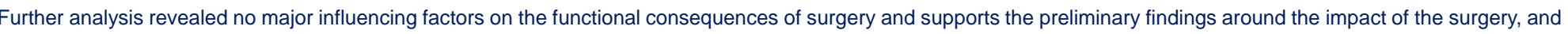
the consequential coping and resilience demonstrated by the women following LD breast reconstruction.

\section{References}

[1] Senkus, E., Kyriakides, S., Penault-Llorca, F. Poortmans, P.. Thompson, A., Zackrisson, S. \& Cardoso, F. (2013) Primary breast cancer: ESMO Clinical Practice Guidelines for diagnosis, treatment and follow-up. Annals of Oncology, 24 (6).

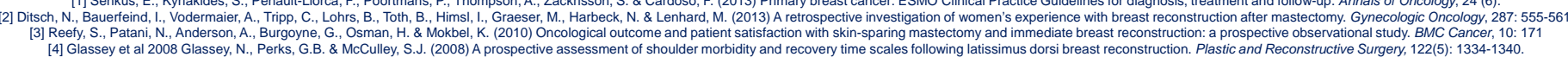
[5] Giordani et al 2010 Giordano, S., Kaariainen, M., Alavaikko, J., Kaistila, T. \& Kuokkanen, H. (2011) LD free flap harvesting may affect the shoulder joint in long run. Scandinavian Journal of Surgery, 100(3): 202-207.

[6] Forthomme, B. Crisier, J, L. Heymans, O Jacquemin, D., Klinkenberg, S., Hoffmann, S., Grandjean, F., \&. Creilaard, J.M. (2010) Shoulder function after latissimus dorsi transfer in breast reconstruction. Clinical Physiology Functional Imaging, 30: 406-412. [7] Smith, S.L. 2014, "Functional morbidity following latissimus dorsi flap breast reconstruction.", Journal of the advanced practitioner in oncology, vol. 5, no. 3, pp. 181-7.

1. PhD Student, Ulster University, Centre for Health and Rehabilitation Technologies, Institute of Nursing and Health Research 2. Lecturer in Physiotherapy, Ulster University, Centre for Health and Rehabilitation Technologies, Institute of Nursing and Health Research 